\title{
The impact of traditional sex practices on the construction of female sexuality: an African human rights perspective*
}

\author{
LETETIA VAN DER POLL \\ Associate Professor, Faculty of Law, University of the Western Cape
}

\begin{abstract}
'The time has come to recognize that denials of individuals' rights on the ground only that they are women are human rights violations, and to require state practices that expose women to degradation, indignity, and oppression on account of their sex to be independently defined, condemned, compensated, and, preferably, prevented. The purpose of changing ubiquitous state practice may appear ambitious, but it is not too ambitious for the needs of our time.'1

'[This Protocol] reaffirms the principle of promoting gender equality as enshrined in the Constitutive Act of the African Union as well as the New Partnership for Africa's Development, relevant Declarations, Resolutions and Decisions, which underline the commitment of the African States to ensure the full participation of African women as equal partners in Africa's development.'2

'The substantive realisation of equality is a precondition for transformative change in South Africa. Yet, inequality is still the biggest challenge facing development and transformation in post-apartheid South Africa.' ${ }^{3}$
\end{abstract}

\section{INTRODUCTION}

Few would challenge the contention that violence against women has reached distressing levels, and, consequently, calls for serious debate and deliberation. Although many attempts have been made since the late 1960s to make critical sense of this worrying phenomenon, the discourse driven by feminism

* This article is based in part on the paper 'The impact of African sex practices on the construction of female sexuality: A constitutional perspective (Human rights and sexuality in Africa)' presented at an international colloquium on Femmes et développement. La dimension juridique hosted by the Institut Catholique de Madagascar in Antananarivo, Madagascar, on May 23, 2008.

1 Cook RJ 'State accountability under the Convention on the Elimination of All Forms of Discrimination Against Women' in Cook RJ (ed) Human rights of women: National and international perspectives (1994) 228.

2 Preamble of the Protocol to the African Charter on Human and Peoples' Rights on the Rights of Women in Africa passed by the Assembly of Heads of the African Union for adoption at its second session in Maputo, Mozambique, on 11 July 2003. The Protocol was the result of protracted negotiations which commenced in 1995 and produced a Draft Protocol which was adopted on 15 November 1999 in Kigali: see 1999 DOC/OS (XXXVII). The last meeting of African government experts to negotiate the Draft Protocol took place in November 2001 in Addis Ababa, Ethiopia. See also n 13 below.

3 Jagwanth S and Kalula E 'Preface' in Jagwanth S and Kalula E (eds) Equality law: Reflections from South Africa and elsewhere (2001) ix. 
to conceptualise gender-based and sexually based ${ }^{4}$ violence against women has arguably been the most convincing, and, accordingly, valuable, of these. Many of the ensuing feminist conceptions of violence against women ${ }^{5}$ can with relative ease - and with a fair degree of success - be transposed to legal discourse. Such a transposition could, in turn, facilitate both a useful and nuanced analysis of the human rights implications of gender-based and sexually based violence.

It is generally accepted within feminist discourse that violence against women emanates from (patriarchal) power and control, finding expression in both physical and sexual violence. ${ }^{6}$ No attempt to make critical sense of violence can, therefore, shy away from the impact of female sexuality on women's oppression, no matter how controversial (or sensitive) this may seem. The (re-) emergence of the practices of dry sex and virginity testing in traditional (African) societies must be seen within this context. This will, in turn, necessitate the formulation of an appropriate (legal/human rights) response.

Such a response could take various forms. It could, for example, be argued that dry sex and virginity testing are useful and valuable traditional practices that seek to uphold cultural values in an increasingly westernised society. It could even be said that these two practices constitute appropriate responses to the HIV/AIDS pandemic in Africa. However, dry sex and virginity testing could also be seen as decidedly harmful, in that they seek to maintain (and indeed entrench) the cultural and sexually based subordination of women in Africa.

This article will explore the nature of gender-based and sexually based violence, with particular reference to the conception within the latter of dry sex and virginity testing. This will be undertaken against the backdrop of three key African human rights instruments - the African Charter on Human and Peoples' Rights (the African Charter), ${ }^{7}$ the Protocol to the African Charter on

4 The 'sex'/'gender' distinction is fundamental to feminist discourse. The term 'gender' is widely used and understood in feminist theory to signify the socially constructed identity of men and women expressed in terms of being 'male' and 'female'. 'Sex' is thus understood to be a biological term; 'gender' a politically and culturally defined one. But since distinctions of gender, based on sex, structure virtually every aspect of our human reality, gender becomes the way in which one group is both socially differentiated from, and subordinated to, the other. The sex/gender distinction thus in effect becomes blurred and the terms could be used interchangeably. This is particularly evident in instances of so-called 'gender-based' and so-called 'sexually based' violence. The former would include the latter: see, in particular, Van der Poll L The constitutionality of pornography (2001) 281 - 283. See also Van der Poll L 'The emerging jurisprudence on sexual violence perpetrated against women during armed conflict' (2007) African Yearbook on International Humanitarian Law 8, and n 43 and $n 127$ below.

5 Although various schools of feminism have sought to make sense of sex-specific violence against women, the arguments advanced, and conceptions formulated, by the more radical streams of feminism have been the most plausible and academically sound. Some of these arguments will be considered in this article: see, in particular, part 4 and accompanying footnotes below.

6 See $n 43$ below. According to the Domestic Abuse Intervention Project of Minnesota, USA, violence against women includes: (a) the use of intimidation; (b) emotional abuse; (c) the use of isolation (eg controlling the victim's actions and restricting freedom of movement); (d) minimising and denying the abuse, and blaming the victim; (e) the use of children (eg making the victim feel guilty about the children); (f) the use of male privilege; (g) economic abuse; and (h) the use of coercion and threats.

77 OAU Doc CAB/LEG/67/3 rev 521 ILM 59 (1981). 
Human and Peoples' Rights on the Rights of Women in Africa (the African Women's Protocol), ${ }^{8}$ and the Constitution of the Republic of South Africa, 1996 (the Constitution). ${ }^{9}$ This will, inter alia, be done with a view to engender a suitable conception of (female) sexuality and human rights within African jurisprudence.

\section{DEFINING 'HARM'}

Any attempt to conceptualise a traditional practice as (inherently) harmful (to women) is steeped in controversy, as it requires an appropriate test or suitable measure. Often the dichotomy that exists between African and western values is employed. Such a standard is not, however, appropriate, as it fails to appreciate the reality of marginalisation and the (often extreme) consequences of societal power, particularly in traditional societies. Moreover, such a standard fails to engage with (and thus consider) the impact of (sexual) politics, and the disregard for the risks associated with a particular traditional practice or (interrelated) practices. Power struggles, local and national politics, and/or lack of understanding about the risks associated with a given practice often determine the success or failure of attempts to conceptualise a traditional practice as harmful. ${ }^{10}$

Various international and regional human rights instruments seek to protect women from discriminatory and abusive practices. These instruments may prove to be particularly useful in conceptualising a sexually based practice as (inherently) harmful to women. A basic argument against gender-specific discrimination on cultural (or customary) grounds could thus be formulated with relative ease. Such an argument could, by definition, also implicate cultural practices specifically detrimental to the health of women. ${ }^{11}$

The African Charter, for example, includes express references to harmful gender-specific practices. ${ }^{12}$ So, too, does the African Women's Protocol. ${ }^{13}$ The African Women's Protocol, adopted in $2003,{ }^{14}$ seeks to address particular issues affecting women, as these have emerged subsequent to the adoption of the African Charter in 1986. The African Women's Protocol specifically articulates the concern that, despite the ratification of the African Charter

8 See $n 2$ above.

9 When passed in 1996, the Constitution was referred to as the 'Constitution of the Republic of South Africa, 1996 (Act 108 of 1996)'. However, pursuant to the coming into operation of the Citation of Constitutional Laws Act 5 of 2005, the Constitution is now cited as 'Constitution of the Republic of South Africa, 1996' and no longer has any Act number.

10 See, in general, Reproductive Health Outlook 'Harmful traditional practices: Overview and lessons learned' (2002) available at www.rho.org/html/hthps_overview.html\#introduction [accessed 30/04/08].

11 The impact of dry sex and virginity testing on the health of women per se, including perspectives on women's reproductive health, will not, however, form the primary object of this article.

12 Article 18(3) of the African Charter expressly states that 'states shall ensure the elimination of every discrimination against women and also ensure the protection of the rights of the woman and child as stipulated in international declarations and conventions'. My emphasis.

13 See, in particular, Art 5 of the African Women's Protocol. By comparison, Art 19(2)(b) and Art 17 of the Draft Protocol, respectively, granted women protection from all forms of intolerance, as well as repugnant cultural and religious practices, and the right to a positive cultural context.

14 See $n 2$ above. 
and other international human rights instruments by the majority of States Parties (and their solemn commitment to eliminate all forms of discrimination and harmful practices against women), women in Africa continue to be victims of discrimination and harmful practices. To this end the African Women's Protocol endeavours to promote and protect a wide range of human rights, including the right to life, integrity and security of the person, ${ }^{15}$ protection from harmful traditional practices, ${ }^{16}$ and protection of women in armed conflict. ${ }^{17}$ The African Women's Protocol makes specific reference to the rights of women recognised and guaranteed in all international human rights instruments, notably, the Universal Declaration of Human Rights, ${ }^{18}$ the International Covenant on Civil and Political Rights, ${ }^{19}$ the International Covenant on Economic, Social and Cultural Rights ${ }^{20}$ and the Convention on the Elimination of All Forms of Discrimination Against Women (CEDAW) ${ }^{21}$ (and its Optional Protocol). ${ }^{22}$

Both the African Women's Protocol and CEDAW are used as interpretive tools by the African Commission on Human and Peoples' Rights (the African Commission). ${ }^{23}$ The African Charter, in turn, makes express reference to CEDAW and grants women all rights recognised under international law. ${ }^{24}$ The common objective is the prohibition of harmful gender-specific practices, irrespective of whether they are culturally or traditionally sanctioned.

\section{TRADITIONAL SEX PRACTICES OF DRY SEX AND VIRGINITY TESTING}

\subsection{Dry sex and vaginal drying}

Dry sex involves the insertion of various drying or absorbent materials or agents into the vagina before (or during) sexual intercourse. A dry sex preparation may consist of vinegar, bleach, chlorine, toothpaste, soaps, powders or herbal potions. ${ }^{25}$ These absorbent materials or agents are inserted into

15 See Art 4 of the African Women's Protocol.

16 See Art 5 of the African Women's Protocol.

17 See Art 11 of the African Women's Protocol.

18 GA Res 217A(III); UN Doc A/810 (1948); UN Doc A/811, 10 December 1948.

19 GA Res 21/2200A, GAOR, 21st Session, Supp, UN Doc A/6316 (1966), UNTS 171, entered into force 23 March 1976.

20 GA Res 21/2200A, GOAR, 21st Session, Supp, UN Doc A/6316 (1966), 993 UNTS 3, entered into force 3 January 31976.

21 Ga Res 34/180 (1979). CEDAW was adopted unanimously by the United Nations on 18 December 1979, opened for signature on 1 March 1980, and entered into force on 3 September 3 1981, following receipt of the 20th ratification. CEDAW is widely acknowledged as the primary instrument to challenge the violation of women's civil and political rights under international law.

22 GA Res A/54/4 (1999).

23 The African Commission on Human and Peoples' Rights is charged by the African Charter to adjudicate complaints that challenge the actions of states under the provisions of the Charter.

24 Article 18(3) of the African Charter expressly refers to the protection of women's rights as encapsulated not only in the Charter itself, but also in other (international) human rights instruments.

25 Soul City et al HIV/AIDS: A resource for journalists (undated) $32-33$, cited in Combrinck $\mathrm{H}$ and Wakefield L 'Section 2: Understanding the context' in Combrinck H and Wakefield L At the crossroads: Linking strategic frameworks to address gender-based violence and HIV/AIDS in Southern Africa (2007) 23 n 31 . 
the vagina in order to rid the vagina of any moisture or natural lubrication. ${ }^{26}$ The intention is to achieve a hot, tight and dry sexual experience greatly sought after by men. ${ }^{27}$ It need not be argued that the desired result is not realised without a great deal of pain and discomfort. The vaginal walls swell in response to the drying agents, thus creating the impression that the vagina is smaller, and the penis consequently larger. ${ }^{28}$

Although the reasons for this practice are varied, commonalities do exist. Dry sex and vaginal drying are thought to minimise the number of girlfriends a husband is likely to have, and may even serve to prevent separation or divorce, as a loose vagina is considered an indication of infidelity. Men in traditional societies apparently also consider vaginal fluids to be unclean. This explains why the practice of dry sex is extremely popular in sub-Saharan Africa, ${ }^{29}$ and sex workers servicing the major truck stops in South Africa reportedly charge more for a dry sex experience. ${ }^{30}$ Men interviewed in focus groups reported mixed feelings about dry sex, yet expressed a dislike for vaginal fluids; thus concluding that there was no other option but for the practice to continue.

The sexual health implications for both sexes are immense. AIDS workers argue that dry sex increases the risk of condom tearing, as friction during intercourse is greater. ${ }^{31}$ In instances where no condoms are used, the probability increases that the vaginal wall will tear. Consequently women are exposed to an even greater risk of contracting the HIV virus or sexually transmitted disease (STD) infections. ${ }^{32}$

\subsection{Virginity testing}

Virginity testing currently enjoys a spirited revival in South Africa. The main rationale behind the practice appears to be the HIV/AIDS pandemic. Virginity testing, as practised in traditional communities, requires mature women to insert their fingers into the vagina to ascertain whether the hymen is still intact. Those who pass the test are certified as virgins for a nominal fee of R5.00. ${ }^{33}$ Certified virginity is greeted with praise and ululation. ${ }^{34}$ The age group of girls subjected to virginity testing varies, as tests may be conducted at the request of either parents or the community. This has produced a situation where children as young as three years have reportedly been subjected

26 See n 25 above.

27 See Morar NS and Karim SSA 'Vaginal insertion and douching practices among sex workers at truck stops in KwaZulu-Natal' (1998) 88 South African Medical Journal 470.

28 See Schoofs M 'The village voice: Aids - the agony of Africa' Part 5 Death and the second sex available at www.africa.com/column/aids_06.html [accessed 30/04/08].

29 See $n 10$ above.

30 See $n 27$ above.

31 See n 25 above.

32 See, in general, Inter-African Committee on Traditional Practices Affecting the Health of Women and Children Report on the regional seminar on traditional practices affecting the health of women and children in Africa (1987 and 1990).

33 Approximately US 50c.

34 See Bell N 'Virginity newly prized in the age of AIDS' available at www.africana.com/dailyarticles/ index_2000133.html_2k [accessed 30/04/08]. 
to testing. ${ }^{35}$ With the high incidence of child abuse in South Africa, the testing of pre-pubescent girls is apparently sanctioned as a means to detect sexual abuse. An intact hymen would suggest the absence of sexual abuse. ${ }^{36}$ Noteworthy is the testing of women who are in their fifties, a practice seemingly intended to lend prestige and legitimacy to virginity testing. Since certified virginity is considered a sign of purity and well-being in traditional societies, it is a decisive factor in determining the bride price during lobola (dowry) negotiations. In KwaZulu-Natal, for instance, the standard lobola price per bride is reported to be ten head of cattle; certified virgins will fetch eleven head of cattle. ${ }^{37}$

The pervasive (African) myth that sexual intercourse with a virgin cures HIV/AIDS has been widely reported. ${ }^{38}$ Virginity testing may unwittingly render women even more defenseless against acts of sexual violence, notably rape. Moreover, the practice of virginity testing may encourage young girls to engage in unprotected anal sex, ${ }^{39}$ thus indeed increasing the risk of HIV/AIDS infection..$^{40}$ In addition, certified virginity may also render women extremely vulnerable to abduction, and the practice of gang rape. As Carol Bower rightly argues:

'In a society with high levels of gang-related activities, where the rape, and even murder, of a virgin forms part of the initiation of gang members, public identification of virgins could become a death sentence. ${ }^{41}$

When subjected to logical and critical scrutiny, the practice of virginity testing is shown to render those who are already at risk potentially more vulnerable to harm, violence and exploitation.

\section{IS IT A QUESTION OF POWER? BELIEFS THAT DRIVE TRADITIONAL PRACTICES}

The sex difference is arguably one of power. ${ }^{42}$ Patriarchal societies are fundamentally hierarchal, engineered to sustain sex inequality. ${ }^{43}$ Male control over

35 See n 34 above.

36 See n 34 above.

37 See also n 33 above.

38 See, for example, Joubert JJ 'Zuma steun “as vader” maagdelikheidstoetse' available at www.news.24. com/Die_Burger/Nuus/0,4-75_1626421,00.html [accessed 25/11/04]; and Clayton J 'South Africa ready to ban "degrading” virginity tests' available at www.timesonline.co.uk/article/0,,3-1927475,00. html [accessed 18/04/06].

39 Hlongwa W 'Teens turn to anal sex to keep virginity', cited in Bower C 'Virginity testing: In whose interest?' (November 2005) Aids Legal Quarterly 9 n 11.

40 See, in general, Stein J 'Virginity test in Aids war' available at www.news24.com/citypress/citypressnews01885,186_906042,00.html [accessed 30/04/08]. See also note 87 below.

41 Bower C 'Virginity testing: In whose interest?' (November 2005) Aids Law Quarterly 9. The author is the Executive Director of Resources Aimed at the Prevention of Child Abuse and Neglect (RAPCAN), South Africa.

42 See, in particular, MacKinnon CA 'The liberal state' in MacKinnon CA Toward a feminist theory of the state (1989) 160 and Bryson V 'Modern radical feminism: Knowledge, language and patriarchy' in Bryson V Feminist political theory: An introduction (1992) $222-231$. See also n 4 above.

43 See, in this regard, MacKinnon CA Toward a feminist theory of the state (1989) n 39160 n 39 ; Hanmer J 'Violence and the social control of women' in Littlejohn G et al Power and the state (1978) 229; and Vance CS 'Pleasure and danger: Toward a politics of sexuality' in Vance CS (ed) Pleasure and danger: Exploring female sexuality (1992) 3. 
female sexuality could thus be seen as the origin, or root cause, of women's (sexual) subordination. ${ }^{44}$

As the dominant group, (heterosexual) men construct (female) sexuality solely for their intended benefit and pleasure. This occurs through the powerful, all encompassing process of (sexual) objectification. Conceptualised within this particular paradigm, male control over female sexuality, facilitated through the sexual objectification of the female, thus constitutes violence per $\mathrm{Se}^{45}$

It need not be argued that dry sex and virginity testing implicate both women's agency and their sexuality. A due appreciation of the material conditions of (African) women's lives, particularly as these are revealed in relation to their sexuality, sharply calls into question the extent to which women can be construed as free, independent agents, exercising unrestricted choices as a free expression of their sexual desires. Consequently the beliefs that drive and sustain cultural sex practices warrant closer inspection.

Cultural beliefs attribute value to traditional practices, and attach sanctions to non-compliance. Women's sexuality is directly implicated by practices and sanctions emanating from societal sex norms. The traditional understanding of vaginal fluids, for example, is centred on 'uncleanness', and its supposedly negative impact on fertilisation. Dry sex thus serves as a direct means to clean and strengthen the body, tone the pelvic muscles, cure STDs, maintain both male and female sexual fidelity, and even curb the scourge of HIV/ AIDS. ${ }^{46}$ Yet Leclerc Madlala rightly questions the latter justification for dry sex in a South African context. She points out that in a country that bears the dubious distinction of having the world's highest statistics for rape, virginity testing is nonsensical as an Aids preventative measure'. ${ }^{47}$

It need not be argued that women lack societal power to influence core beliefs that impact on their sexuality, and indeed their very identity. Moreover, the sole responsibility and accountability for sexual behaviour is placed on women in a sphere where men enjoy the greater power and influence.

The pressure to satisfy men sexually is further underscored by the fact that women in traditional societies routinely visit traditional healers to undergo a procedure expressly intended to attract male sexual attention. ${ }^{48}$ The procedure requires a small incision to be made in the labia. This is done with the aid of an ordinary razor blade, whereafter herbal substances are rubbed into the wound. The practice, referred to as ukugcaba, is performed every two months, and it is believed that, once these herbal substances enter the blood,

44 See Itzin C 'Pornography and the social construction of sexual inequality' in Itzin C (ed) Pornography, violence and civil liberties (1992) $65-68$ and Steinem G 'Erotica and pornography: A clear and present difference' in Lederer L (ed) Take back the night: Women on pornography (1982) 37 - 38.

45 See Rubin G 'Feminism and participatory democracy: Some reflections on sexual difference and citizenship' in Kemp S and Squires J (eds) Feminisms (1997) 196.

46 See $n 28$ above.

47 Cited in Schoofs M (n 28 above).

48 See n 29 above. 
the sexual attention of the opposite sex will be aroused. ${ }^{49}$ As Carol Bower rightly observes:

'Notions of [girls] as owned by their parents and of their virginity status as representing the "honour" of their families, lie behind the insistence of knowing whether or not the hymen is intact. It remains true in South Africa that women's status is largely determined by their relationship to men - father, husband, brother or son. For this system to work, it is absolutely necessary to know to whom each child born "belongs" - i.e. who is that child's father?'50

It could well be argued that the abuses of women result from, and are compounded by, their social, economic and political inequalities. Lack of access to education, land, financial resources, and health care, coupled with women's inequality within the family, render it virtually impossible for them to live free from (sexual) abuse and violence. Viewed through this particular (feminist) lens, the two practices are not all that different. Social coercion is, after all, fundamentally driven by patriarchal needs and desires, expressed through the medium of (female) sexuality. Arguments supporting women's agency and the idea that women, as a group, can freely express their sexual desire within such a decidedly patriarchal social, economic and political context thus become highly suspect.

Since many abuses of women's rights, especially gender violence, result from private action, it becomes imperative to invoke human rights standards as a defence against such abuses. The possible human rights implications of dry sex and virginity testing will be considered next.

\section{DRY SEX AND VIRGINITY TESTING: TRADITION OR (SEX) SUBORDINATION?}

\subsection{An African perspective}

\subsubsection{The African Charter}

The African Charter entrenches rights and freedoms similar to those commonly found in international and regional human rights documents. To this end Article 2 reads:

'Every individual shall be entitled to the enjoyment of the rights and freedoms recognised and guaranteed in the present Charter without distinction of any kind such as race, ethnic group, colour, sex, language, religion, political or any other opinion, national and social origin, fortune, birth or other status.'

This non-discrimination clause thus expressly prohibits differentiation on the basis of sex. In addition, every individual is considered to be equal before the law and shall be entitled to equal protection of the law. ${ }^{51}$ The African Charter also expressly recognises the right to liberty and security of the person, albeit in rather gender-insensitive terms. ${ }^{52}$ Article 18 recognises the family

\footnotetext{
49 See n 29 above.

50 Bower C (n 41 above) 7. Emphasis in the original.

51 Article 3 of the African Charter stipulates: '1. Every individual shall be equal before the law. 2. Every individual shall be entitled to equal protection of the law.'

52 Article 6 of the African Charter states: 'Every individual shall have the right to liberty and to the security of his person.' My emphasis.
} 
as the natural unit and basis of society, whose physical and moral health shall be protected by the state. ${ }^{53}$ The family is furthermore acknowledged as the custodian of morals and traditional values recognised by the community, and the state is likewise expected to assist the family in discharging its duty as custodian of these values. ${ }^{54}$ Article 18 also places a specific obligation on the state to eliminate every discrimination against women. To this end Article 18(3) stipulates that:

'The State shall ensure the elimination of every discrimination against women and also ensure the protection of the rights of the woman and the child as stipulated in international declarations and conventions.'

The African Charter thus acknowledges, and accentuates, the importance of recognising the protection afforded to women and children under various international human rights documents. Yet the African Charter also appears to be couched in decidedly communitarian terms, thus advancing a distinctive communitarian conception of human rights. ${ }^{55}$ The manner in which the African Charter is perceived and interpreted will therefore be decisive factors in the advancement of (women's) rights.

The African conception of human rights is generally viewed with suspicion by western thinkers. ${ }^{56}$ The African notion that the individual is submerged in the community is often criticised, and seen as an attempt to marginalise (and thus discard) rights and freedoms typically afforded to individuals or groups of individuals. ${ }^{57}$ It follows that, if African societies embrace a communitarian understanding of human rights, issues affecting women are likely to be overlooked. The fact that most African societies are also deeply patriarchal further compounds women's dilemma.

In addition, the legal, political and social obligations of states toward individuals are thought to be situated in the public sphere. Consequently a clear distinction is typically drawn by western thinkers between the public and private spheres.58 In an acknowledgement of the moral autonomy of the individual, the state may only interfere in the public domain. ${ }^{59}$ Interna-

53 Article 18(1) of the African Charter reads: 'The family shall be the natural unit and basis of society. It shall be protected by the State which shall take care of its physical health and moral health.'

54 Article 18(2) provides: 'The State shall have the duty to assist the family which is the custodian of morals and traditional values recognised by the community.'

55 See $\mathrm{n} 53$ and n 54 above.

56 See, in general, Howard R 'Communitarianism and liberalism in the debates on human rights in Africa' (1992) 11 Journal of Contemporary African Studies 1.

57 See, in general, Sanders AJGM 'On African socialism and natural law thinking' (1978) 11 Comparative and International Law Journal of Southern Africa 68 and Sanders AJGM 'On African socialism and the rule of law' (1982) 15 Comparative and International Law Journal of Southern Africa 299.

58 This distinction is common in liberal political theory: see, in general, Borchorst A and Siim B 'Women and the advanced welfare state - A new kind of patriarchal power' in Sassoon AS (ed) Women and the state: The shifting boundaries between public and private (1987); Herness H 'The welfare state, citizenship and Scandinavian women' in Jones K and Jonasdottir A (eds) The political interests of gender: Developing theory and research with a human face (1988); Siim B 'Welfare state, gender politics and equality principles: Women's citizenship in the Scandinavian welfare state' in Meehan E and Sevenhuijsen S (eds) Equality principles and politics (1991); and Smart C Feminism and the power of law (1989).

59 See Fallon R 'What is republicanism and is it worth reviving?' (1989) 102 Harvard Law Review 1695 and Gardbaum S 'Law, politics and the claims of community' (1992) 90 Michigan Law Review 685. 
tional human rights instruments have, however, sanctioned increased and legitimised state interference in the private sphere. The African Commission, indeed, interprets the African Charter with due appreciation of the rights and freedoms of the individual. To this end the African Commission rejects the alienation and subordination of the individual, and promotes the coexistence of individuals within the community. ${ }^{60}$ Any notion of the individual in opposition to the community thus appears to be rejected by the African Commission.

Moreover, the African understanding of the relationship between the state and the individual shows no clear distinction or demarcation between the public and private spheres. ${ }^{61}$ The state is present in both public and private life. 'The state is not above, nor outside, nor sovereign ... [it] co-exists, coinhabits [and] communicates with the society from which it is inseparable. ${ }^{62}$ Since there is no separation of civil society and the state, the African Charter has both vertical ${ }^{63}$ and horizontal ${ }^{64}$ application. It could well be argued that states have to take appropriate measures that ensure the elimination of all forms of discrimination against women that typically occur in the private domain.

It must be stressed that practices that harm the individual ultimately cause disunity in (and therefore harm to) the community. ${ }^{65}$ Traditional practices that are harmful cannot be used as a means to justify the subordination of the individual to the group. ${ }^{66}$ This would, in fact, stand in direct opposition to the spirit of both the African Charter and the African Women's Protocol.

A violation of the individual is a violation of the collective. ${ }^{67}$ The obligation of African states is, therefore, to ensure that tradition does not sanction practices that violate the dignity and security of the individual. ${ }^{68}$ More specifically, states are compelled under the African Charter to eradicate every

60 See Murray R 'The Notion of a State' in Murray R (ed) The Commission on Human and Peoples' Rights and International Law (2000) 34.

61 In contrast to the strict demarcation commonly encountered in classical liberal philosophy: see, in particular, $n 58$ above.

62 See Murray R (n 60 above) 35 .

63 The narrowest conception of a Charter of Rights is that it contains so-called 'negative liberties': see Posner J in Jackson v City of Joliet 715 F 2d 1200, 1203 (7th Cir) (1983) 1206. This means that it is intended to protect individuals against state power by listing rights that cannot be violated by the state, either by means of law or through the conduct of state actors. This 'vertical' relationship thus exists between individuals and the state.

64 A Charter of Rights that has solely vertical application will place duties on the state not to violate the rights of individuals, but will not place similar duties on individuals. The 'horizontal' application of a Charter of Rights thus implies that individuals are directly bound to uphold constitutional rights: see, for example, Du Plessis $v$ De Klerk 1996 (3) SA 850 (CC) para 45.

65 See S v Makwanyane 1995 (3) SA 391 (CC) where O'Regan J explained that Black people were not afforded respect during the apartheid era. The mere denial of respect to one group of persons meant the denial of respect to the community as a whole. The African Commission maintains this understanding of the individual and the community. The denial of human dignity to one group (women) will impact on the community as a whole.

66 See, in general, Sohn L 'Protection of individuals' (1982) 32 American Law Review 17 - 18.

67 See Umezurike O 'The status of human rights' (1995) 5 Constitutional Rights Journal 11.

68 See Murray R (n 60 above) 38. 
discrimination against women. ${ }^{69}$ When coupled with the African Women's Protocol's commitment to eradicate gender-specific violence, the practices of dry sex and virginity testing cannot remain unchallenged. A discussion of some pertinent aspects of the African Women's Protocol follows next.

\subsubsection{The African Women's Protocol}

The African Women's Protocol expresses in its Preamble the firm conviction that 'any practice that hinders or endangers the normal growth and affects the physical and psychological development of women and girls should be condemned and eliminated'. The Preamble furthermore expresses the determination to 'ensure that the rights of women are promoted, realised and protected in order to enable them to enjoy fully all their human rights'.

The definition clause of the African Women's Protocol, inter alia, conceptualises 'discrimination against women', 'harmful practices', and 'violence against women'. Article 1(f) stipulates that 'discrimination against women' means:

'any distinction, exclusion or restriction or any differential treatment based on sex and whose objectives or effects compromise or destroy the recognition, enjoyment or the exercise by women, regardless of their marital status, of human rights and fundamental freedoms in all spheres of life'.

'Harmful practices' are defined as:

'all behaviour, attitudes and/or practices which negatively affect the fundamental rights of women and girls, such as their right to life, health, dignity, education and physical integrity'. ${ }^{70}$

In turn, violence against women includes 'all acts perpetrated against women which cause (or could cause) them physical, sexual, psychological and economic harm'. This also includes 'the threat to take such acts'. ${ }^{71}$

The obligation of States Parties to eliminate discrimination against women is articulated in Article 2. States Parties are required to 'combat all forms of discrimination ${ }^{72}$ against women through appropriate legislative, institutional and other measures'. In particular, appropriate legislative or regulatory measures must be effectively implemented to curb 'harmful practices which endanger the health and general well-being of women'. ${ }^{73}$ Moreover, States Parties are required to 'integrate a gender perspective in their policy decisions, legislation, development plans, programmes and activities', as well as in 'all other spheres of life'. ${ }^{74}$ It is of particular significance to note that corrective and positive action must be taken in those areas where discrimination against women continues to exist in law and in fact. ${ }^{75}$ Article 2, therefore, places a positive obligation upon States Parties to actively address all prac-

\footnotetext{
69 See Art 18(3) of the African Charter. See also n 53 and n 54 supra.

70 See Art 1(g) of the African Women's Protocol.

71 See Art 1(j) of the African Women's Protocol. My emphasis.

72 My emphasis.

73 See Art 2(b) of the African Women's Protocol

74 See Art 2(c) of the African Women's Protocol.

75 See Art 2(d) of the African Women's Protocol.
} 
tices deemed harmful to women that impact on, and endanger, the health and general well-being of women in Africa.

The practices of dry sex and virginity testing sharply bring into focus the provisions of the African Women's Protocol that seek to eliminate harmful practices. Article 5 reads:

'States Parties shall prohibit and condemn all forms of harmful practices which negatively affect the human rights of women and which are contrary to recognised international standards. States Parties shall take all necessary legislative and other measures to eliminate such practices... ${ }^{76}$

Article 5 expressly requires States Parties to create, through information, education and outreach programmes, public awareness regarding harmful practices. ${ }^{77}$ In the present context, Article $5(\mathrm{~b})$ is of particular significance. It requires that 'all forms of female genital mutilation, scarification, medicalisation and para-medicalisation of female genital mutilation and all other practices $^{78}$ are to be prohibited (and ultimately eradicated) through 'legislative measures backed by sanctions'. ${ }^{79}$ The subsection thus envisages judicial support for women, including support in the form of health services. ${ }^{80}$ States Parties are furthermore required to protect women who are 'at risk of being subjected to harmful practices or all other forms of violence, abuse and intolerance'. ${ }^{81}$

It was explained above ${ }^{82}$ how the practice of dry sex increases the risk of condom tearing, ${ }^{83}$ and that, in instances where no condoms are used, health workers warn of the increased probability that the vaginal wall will tear. Consequently women are exposed to an even greater risk of contracting the HIV virus, ${ }^{84}$ or STD infections. It was also pointed out above ${ }^{85}$ how the pervasive (African) myth that sexual intercourse with a virgin cures HIV/ AIDS may unwittingly render women even more defenceless against acts of sexual violence, notably rape. Moreover, the practice of virginity testing may in fact encourage young girls to engage in unprotected anal sex, ${ }^{86}$ thus indeed increasing the risk of HIV/AIDS infection. ${ }^{87}$ Both sex practices thus implicate

76 My emphasis.

77 See Art 5(a) of the African Women's Protocol.

78 My emphasis.

79 My emphasis

80 See Art 5(c) of the African Women's Protocol.

81 See Art 5(d) of the African Women's Protocol. My emphasis.

82 See part 3.2 above.

83 See $n 32$ above.

84 See $n 87$ below.

85 See part 3.2 above.

86 See $n 39$ above.

87 South Africa is experiencing a maturing generalised HIV epidemic in which heterosexual sex is the predominant mode of transmission. HIV prevalence remains disproportionately high for females overall in comparison to males, and it peaks in the 25 to 29 age group. The UNAIDS defines South Africa's epidemic as being hyper-endemic as a result of more than $15 \%$ of the population aged 15 to 49 living with HIV. In 2007 an estimated 33 million people were living with HIV globally, with South Africa bearing a disproportionate burden with $35 \%$ of HIV infections occurring in sub-Saharan Africa. In South Africa, the highest prevalence of HIV is found in Kwazulu-Natal (15.8\%), compared to the lowest prevalence in the Western Cape (3.8\%). See, in particular, South African national HIV prevalence, incidence, behaviour and communication survey HSRC (2008) XV and Report on global AIDS epidemic UNAIDS (2008) Geneva. See also Stein J (n 40 above). 
the health and (sexual) well-being of women. The African Women's Protocol entrenches the health and reproductive rights of women, including the right to control their fertility, ${ }^{88}$ the right to choose any method of contraception, ${ }^{89}$ and the right to self-protection (and to be protected) against sexually transmitted infections (STI), 'including HIV/AIDS'. ${ }^{90}$

\subsection{A South African (constitutional) perspective}

The rather modest attempts by the South African legislature to address the practice of virginity testing in so far as children ${ }^{91}$ are concerned, point to the possible human rights implications of this practice. Two earlier versions of the Children's Bill ${ }^{92}$ sought, respectively, to conditionally allow, ${ }^{93}$ and to prohibit, ${ }^{94}$ virginity tests performed on the (girl) child. Both these approaches have been incorporated into the Children's Act. ${ }^{95}$

In terms of section 12 of the Children's Act, social, cultural and religious practices affecting children are considered. To this end section 12(1) stipulates:

'Every child has the right not to be subjected to social, cultural and religious practices which are detrimental to his or her well-being.'

The issue of virginity testing is addressed under four subsections. Section 12 of the Children's Act introduces an age restriction, ${ }^{96}$ allows for informed consent, ${ }^{97}$ and seeks to protect the privacy ${ }^{98}$ and bodily integrity ${ }^{99}$ of the (girl) child. Section $12(4)$ reads:

'Virginity testing of children under the age of 16 is prohibited.'

The question of consent is addressed in section 12(5)(a)-(c) which stipulates:

'Virginity testing of children older than 16 may only be performed (a) if the child has given consent to the testing in the prescribed manner; (b) after proper counselling of the child; and (c) in the manner prescribed.'

Section 12(6) recognises the (girl)child's right to privacy by specifying that the 'results of a virginity test may not be disclosed without the consent of the child'. Questions pertaining to both privacy and bodily integrity are addressed

88 See Art 14(1)(a) of the African Women's Protocol.

89 See Art 14(1)(c) of the African Women's Protocol.

90 See Art 14(1)(d) of the African Women's Protocol.

91 The Children's Act 38 of 2005 defines 'children' as 'human beings under the age of 18'.

92 Children's Bill B70D-2003 published 13 December 2005 and Children's Bill B70B-2003 published 15 June 2005.

93 Children's Bill B70D-2003 (n 92 above).

94 Children's Bill B70B-2003 (n 92 above). See also Children's Institute, University of Cape Town 'Virginity testing and the Children's Bill: Discussion paper' (2005) available at http://web.uct.ac.za/ depts/ci/plr/docs/Virginity\%20Testing\%Discussion\%20Paper\%2010\%200ct\%202005.doc [accessed 30/04/08].

95 Act 38 of 2005.

96 See s 12(4) of Act 38 of 2005.

97 See s 12(5)(a)-(c) of Act 38 of 2005

98 See s 12(6) of Act 38 of 2005.

99 See s 12(7) of Act 38 of 2005. 
in section 12(7), which states that the "body of a child who has undergone virginity testing may not be marked'.

The second version of the Children's Bill had contained a specific provision providing for criminal liability in the event of a contravention of section 12(3) (which proscribed 'genital mutilation or the circumcision of female children') and section 12(4) (which proscribed 'virginity testing of children') ${ }^{100}$. This specific provision was, however, omitted from the Children's Act.

Within the broader African context, Article 17 of the United Nations Declaration on the Rights of the Child ${ }^{101}$ and Article 10 of the African Charter on the Rights and Welfare of the Child (the ACRWC) ${ }^{102}$ both provide that "no child shall be subjected to arbitrary or unlawful interference with his or her privacy, family, home or correspondence or to unlawful attacks on his or her honour and reputation'. Similarly, the 1993 United Nations Conference on Human Rights in Vienna ${ }^{103}$ sounded an historical call by stressing the importance of working towards the elimination of violence against women (and the girl child) ${ }^{104}$ in public and private life, and the eradication of any conflicts which may arise between the rights of women and the harmful effects of certain traditional or customary practices.

South Africa, through the ratification of a number of international treaties and conventions, is bound in terms of international law to recognise and protect the rights of children and to promote their realisation. South African courts are obliged to consider international law when interpreting the South African Constitution and Bill of Rights. ${ }^{105}$ Courts are likewise obliged to give preference to a reasonable interpretation of legislation that is consistent with international law, rather than any alternative interpretation that is inconsistent with international (human rights) law. ${ }^{106}$

Within the African (human rights) context, the African Charter, too, places a distinct obligation on the African Commission to consider international declarations and conventions when considering the elimination of discrimi-

100 The provision read: 'A person who contravenes subsection (3) or (4) or who permits such contravention in respect of a child whom he or she is obliged to protect against maltreatment, abuse or degradation is guilty of an offence.'

101 GA Res 1386 UN GAOR 14th Sess Supp No 16 Agenda Item 6419 UN Doc 4/4354 (1959).

102 Adopted 11 July 111990 and entered into force on 29 November 29 1999: OAU Doc CAB/ LEG/24.9/49 (1999). Article 14 of the ACRWC guarantees to every child the right 'to enjoy the best attainable state of physical, mental and spiritual health'.

103 Vienna Declaration and Programme of Action UIN Doc AV49668 (1993) 14 HRLJ 352, (1993) 32 ILM 1661.

104 See, for example, Art 21 of the Vienna Declaration and Programme of Action which called for universal ratification by 1995 of the 1989 United Nations Convention on the Rights of the Child GA Res 44/25 UN GAOR 44th Sess Supp No 49 UN Doc AV44/736 (1989) (hereinafter referred to as the UNCRC). Article 19 of the UNCRC, for instance, instructs all States Parties to take appropriate measures 'to protect the child from all forms of physical or mental violence, injury or abuse'.

105 See s 39(1) of the Constitution. The African Charter is of regional application. The mode of interpretation favoured by the African Commission may, therefore, have significant impact on municipal legal systems that have ratified the African Charter.

106 See s 233 of the Constitution that reads: 'When interpreting any legislation, every court must prefer any reasonable interpretation of the legislation that is consistent with international law over any alternative interpretation that is inconsistent with international law.' 
nation against women and girls. ${ }^{107}$ The African Commission is further obliged to 'draw inspiration from' ${ }^{108}$ various regional and international human rights instruments, including those adopted by the United Nations and African countries. ${ }^{109}$

The possible impact of dry sex and virginity testing on the constitutionally protected rights to human dignity, freedom and security of the person, equality, and privacy, will each be briefly considered next within the above contextual framework.

\subsubsection{Human dignity}

The right to human dignity proceeds from the assumption that the dignity of all humans must be respected by virtue of their membership of humanity. ${ }^{110}$ Together with equality and freedom, dignity is a core value of the South African legal and constitutional dispensation. ${ }^{11}$

In addressing the constitutional implications of the death penalty in $S \mathrm{~V}$ Makwanyane, ${ }^{12}$ O'Regan J held that human dignity is an acknowledgement of the intrinsic worth of every human being. ${ }^{113}$ On this occasion the Constitutional Court found that the death penalty treated human beings as objects, non-humans at the mercy of the state. The ensuing objectification and reduction in status are inconsistent with human dignity as a core constitutional value. ${ }^{114}$ Chaskalson J noted that, since the rights to life and dignity are the sources of all personal rights, they are fundamental to the rights enshrined in the Bill of Rights. ${ }^{115}$ Chaskalson J furthermore reiterated that, in the new South African dispensation, society is required to recognise life and dignity as precursors to all other rights conferred on the individual. ${ }^{116}$

Any practice that serves to objectify human beings violates the intrinsic worth of the individual. The practices of dry sex and virginity testing implicate women's very (sexual) identity. These practices reduce women to sex objects, and thus impact on their status and value as human beings. It follows that dry sex and virginity testing cannot be tolerated by a legal community commit-

107 As expressed in Art 18(3) of the African Charter. See also n 53 and n 54 above.

108 See Article 60 of the African Charter that, by implication, refers to the protection afforded by CEDAW. See also Art 61 of the African Charter that requires that the African Commission consider African practices found to be consistent with international human rights norms.

109 Art 60 reads: 'The [African] Commission shall draw inspiration from international law on human and peoples' rights, particularly from the provisions of various African instruments on human and peoples' rights, the Charter of the United Nations, the Charter of the Organization of African Unity, the Universal Declaration of Human Rights, other instruments adopted by the United Nations and by African countries in the field of human and peoples' rights as well as from the provisions of various instruments adopted within the Specialized Agencies of the United Nations of which the parties to the present Charter are members.'

110 Section 10 of the Constitution reads: 'Everyone has the right to human dignity.'

111 These three values are enshrined in ss $1(a), 7(1), 9,10,36(1)$ and $39(1)(a)$ of the Constitution.

1121995 (3) SA 391 (CC).

113 At para 328 .

114 At paras $328-329$.

115 At para 144 .

116 At para 144. 
ted to the eradication of all practices and traditions that violate the inherent dignity of an historically marginalised group, notably women. ${ }^{117}$

\subsubsection{Freedom and security of the person}

The South African Bill of Rights also entrenches the freedom and security of every person. ${ }^{118}$ To this end section 12 protects both the physical and psychological integrity of the individual. ${ }^{119}$ The nature and extent of the state's obligation in terms of section 12 were considered in Carmichele $v$ Minister of Safety and Security. ${ }^{120}$ In this instance the Constitutional Court held that the state was obliged, through its organs, to respect, promote and protect the dignity, freedom and security of every individual. In particular, the right of women to be free from the threat of sexual violence was stressed. ${ }^{121}$ The state is, therefore, not merely obliged to proscribe harmful practices of a sexual nature, but is in fact reminded of its legal obligation to enforce all laws prohibiting sexual violence against women.

The Carmichele decision is of particular significance in assessing the role of the state and its agents in relation to potentially harmful traditional practices. States may no longer pay mere lip service to the protection afforded to women under various national, regional and international human rights instruments. Instead, states must actively enforce mechanisms that seek to safeguard women from (sexual) harm. African states are thus compelled to realise the protection afforded to women under the African Charter and the African Women's Protocol. It follows that traditional practices, such as, dry sex and virginity testing, will not prevail, once these are subjected to appropriate constitutional scrutiny.

\subsubsection{Equality}

The question whether a law or practice violates the non-discrimination provision contained in section 9(3) of the Constitution ${ }^{122}$ was considered in President of the Republic of South Africa v Hugo ${ }^{123}$ and in Harksen $v$ Lane NO. ${ }^{124}$ In these

117 See Art 5 of the African Charter that reads: 'Every individual shall have the right to the respect of the dignity inherent in a human being and to the recognition of his legal status. All forms of exploitation and degradation of man, particularly slavery, slave trade, torture, cruel, inhuman or degrading punishment and treatment shall be prohibited.'

118 See also Art 6 of the African Charter that reads: 'Every individual shall have the right to liberty and to the security of his person. No one may be deprived of his freedom except for reasons and conditions previously laid down by law. In particular, no one may be arbitrarily arrested or detained.' My emphasis.

119 Section 12 of the Constitution combines a right to freedom and security of the person with the right to bodily and psychological integrity. While the former includes the right to be free from all forms of violence from either public or private sources (s 12(1)(c)), the latter extends to issues concerning (female) reproduction (s 12(2)(a)), as well as security in, and control over, one's body (s 12(2)(b)).

1202001 (4) SA 938 (CC).

121 At paras 30 and 32 .

122 Section 9(3) of the Constitution reads: 'The state may not unfairly discriminate directly or indirectly against anyone on one or more grounds, including race, gender, sex, pregnancy, marital status, ethnic or social origin, colour, sexual orientation, age, disability, religion, conscience, belief, culture, language and birth.'

1231997 (4) SA 1 (CC).

1241998 (1) SA 300 (CC). 
instances the Constitutional Court formulated a test to determine whether or not the differentiation in question is constitutionally problematic. Where the differentiation is based on any of the grounds expressly enumerated in section 9(3), discrimination will have been shown. ${ }^{125}$ In order to assess whether the discrimination is also 'unfair' in the constitutional sense, courts must, inter alia, consider the position of the claimant in society, the nature of the action or provision, and the effect of the provision or action on the claimant's rights. ${ }^{126}$

The traditional practices of dry sex and virginity testing clearly differentiate between men and women on the expressly enumerated (and interrelated) ${ }^{127}$ grounds of sex and gender. ${ }^{128}$ Discrimination will, therefore, have been shown. In order to assess whether said discrimination is also 'unfair', the position of women in (South) African society must be considered.

It need not be argued that (African) women and girls constitute an historically vulnerable and decidedly marginalised group within society. ${ }^{129}$ Dry sex and virginity testing are by their nature invasive and violent. The patriarchal and cultural power in terms of which these practices are sanctioned is deeply entrenched. The impact on women's dignity and their psychological and bodily integrity is severe. The differentiation inherent in these two traditional practices cannot, therefore, be seen as 'fair', in the constitutional sense that this term has acquired. It follows that dry sex and virginity testing could be regarded as unfair discrimination in terms of South African constitutional jurisprudence.

\subsubsection{Privacy}

As pointed out above, ${ }^{130}$ both the testing of virginity and the communication of the results of the test are decidedly public events. Section 14 of the Constitution guarantees the right to privacy. ${ }^{131}$ The South African Human Rights Commission has indeed cautioned that girls identified as non-virgins are exposed to physical and emotional danger. ${ }^{132}$ In addition, girls who have been sexually abused, and who are identified as non-virgins, face increased risks of abandonment, rejection, and violence. Considering the significant negative consequences of being identified as a non-virgin, such public disclo-

\section{At para 49.}

126 At paras $50-51$.

127 Since the dialectical conception of the relation between human nature and human society could be said to challenge the conceptual distinction between sex and gender, the sex/gender distinction becomes superfluous in a feminist critique of female (sexual) subordination: see, in general, MacKinnon CA 'Feminism, Marxism, method, and the state: Toward feminist jurisprudence' (1983) 8 Signs: Journal of Women in Culture and Society 635. See also $n 4$ above.

128 On the significance of this, see $n 127$ and n 4 above.

129 This vulnerability has been duly acknowledged by South African courts: see, in general, Zondi $v$ President of the Republic of South Africa 2000 (2) SA 49 (N) and Bhe $v$ The Magistrate, Khayelitsha 2005 (1) SA 580 (CC).

130 See part 3.2 and accompanying footnotes above.

131 Section 14 of the Constitution reads: 'Everyone has the right to privacy, which shall include the right not to have - (a) their person or home searched; (b) their property searched; (c) their possessions seized; or (d) the privacy of their communications infringed.'

132 South African Human Rights Commission Position paper: Virginity testing (July 2005) 2. 
sure can place the girl or woman at considerable physical and emotional risk. This poses a no-win situation. As Carol Bower explains:

"It really is a "Catch-22 situation" - if she refuses the test, she is suspected of "improper" conduct, if she takes it and fails, she is guilty of "improper" conduct. Either way she is publicly humiliated, devalued, and placed at physical and emotional risk. ${ }^{133}$

In $S v$ Jordan $^{134}$ the Constitutional Court reiterated the correlation between privacy and the value of human dignity. ${ }^{135}$ It is self-evident that both the circumstances under - as well as the context within - which the practice of virginity testing is situated, constitute violations of the right to privacy in terms of section 14 of the Constitution.

\subsubsection{Reasonable and justifiable limitation?}

Once it has been established that a fundamental right has been infringed by law or conduct, the question whether the infringement can be justified as a permissible limitation of the particular right, ${ }^{136}$ must be considered. The criteria for a limitation of rights are laid down in section 36(1) of the Constitution, which stipulates that the law must be of general application and that the limitation is reasonable and justifiable in an open and democratic society based on human dignity, equality and freedom.

Although the Constitutional Court has not directly addressed what would qualify as 'law of general application', it has given a wide interpretation to 'law' elsewhere in the Constitution. This would include all forms of legislation $^{137}$ as well as the common law and customary law. ${ }^{138}$ On the strength of this interpretation, a traditional practice sanctioned by customary law would thus only qualify as 'law of general application' if it applies in the same way to everyone that it regulates. ${ }^{139}$ The question to be decided, therefore, is whether the traditional practices of dry sex and virginity testing are specific or general in their application. If not general, then there can be no 'law of general application' and thus no limitation of a fundamental right. It follows that the rule or practice must not apply solely to an individual case, nor must it restrict the rights only of a particular individual or group of individuals: the rule or practice must provide for parity of treatment - 'like must be treated alike'. ${ }^{140}$ Since both dry sex and virginity testing are traditional practices that women

\footnotetext{
133 Bower C (n 41 above) 8 - 9. Emphasis in the original.

1342002 (6) SA 642 (CC) paras $81-83$.

135 See also part 5.2.1 above.

136 But see Christian Education South Africa v Minister of Education 2000 (4) SA 757 (CC), where the Constitutional Court indicated its willingness to depart from the two-stage approach to rights and their limitation in order to avoid having to decide the question whether a right has been infringed. For a critique of this approach, see De Waal J and Currie I 'Limitation of rights' in De Waal J and Currie I The Bill of Rights handbook (2005) $166 \mathrm{n} 11$.

137 In Larbi-Odam v MEC for Education (North-West Province) 1998 (1) SA 745 (CC) para 27 the Constitutional Court held that subordinate legislation applying to all educators in South Africa was a law of general application.

138 See Du Plessis v De Klerk 1996 (3) SA 850 (CC) paras 44 and 136.

139 Equal application does not mean that a law must apply to everyone, but simply that it applies to everyone that it regulates, for example, broadcasters, in the same way: see Islamic Unity Convention $v$ Independent Broadcasting Authority 2002 (4) SA 294 (CC).

140 De Waal J and Currie I (n 136 above) 174.
} 
are subjected to by virtue of general cultural (or societal) norms and expectations, all women thus subjected are treated and affected in the same manner. The term 'practice' would indeed denote treatment and consequences of such a general (and inescapable) nature, thus implying parity of treatment. As a result, the practices of dry sex and virginity testing could thus be interpreted as 'law(s) of general application' in the constitutional sense that this term has acquired.

The question whether the restriction is reasonable and justifiable in an open and democratic society based on human dignity, equality, and freedom, seeks to ascertain whether the restriction serves a constitutionally acceptable purpose. ${ }^{141}$ There needs to be sufficient proportionality ${ }^{142}$ between the infringement and the purpose(s) of the law, rule or practice, which must be considered with reference to the set of 'relevant factors' contained in section $36 .{ }^{143}$ These factors serve to establish whether the infringement serves a purpose that is considered legitimate by all reasonable citizens ${ }^{144}$ in a constitutional democracy that values human dignity, equality and freedom 'above all other considerations'. ${ }^{145}$

The constitutional impact of the practices of dry sex and virginity testing on women's rights to dignity, equality, freedom and security of the person, and privacy has been argued above. ${ }^{146}$ And since the Constitution 'seeks to establish a society where the individual value of each member of the community is recognised and treasured', ${ }^{147}$ the practices of dry sex and virginity testing stand in direct conflict with the ideal of such a society, and the core constitutional values of human dignity, equality, and freedom. Considered within this particular constitutional context, neither of these two traditional sex practices could thus be deemed constitutionally reasonable and justifiable.

\section{CONCLUDING REMARKS}

It cannot be denied that female sexuality is a determining factor in understanding the particular oppression of women and girls, and the ensuing harm. Dry sex and virginity testing constitute harmful traditional practices that infringe the inherent dignity of women, their freedom and security, and their rights to equality and privacy.

The African Commission does not sanction limitations on the rights of women, nor does it support the subordination of women to the community. African states have an obligation to ensure that the family unit, traditionally a private domain, does not become a haven for harmful sexually based genderspecific practices. That obligation rests on us also. Failure to act decisively

141 S v Makwanyane 1995 (3) SA 391 (CC) para 104.

142 See De Waal J and Currie I (n 136 above) 176.

143 These factors include: '(a) the nature of the right; (b) the importance of the purpose of the limitation;

(c) the nature and extent of the limitation; (d) the relation between the limitation and its purpose;

and (e) less restrictive means to achieve the purpose'.

144 See National Coalition for Gay and Lesbian Equality v Minister of Justice 1999 (1) SA 6 (CC).

145 De Waal J and Currie I (n 136 above) 185.

146 See parts 5.2.1 - 5.2.3 and accompanying footnotes above.

147 Per O'Regan J in S v Makwanyane 1995 (3) SA 391 (CC) para 326. 
will indeed constitute tacit condonation of the sexually based subordination of women and girls.

\section{BIBLIOGRAPHY}

Borchorst A and Siim B 'Women and the advanced welfare state - A new kind of patriarchal power' in Sassoon AS (ed) Women and the state: The shifting boundaries between public and private (1987) London: Hutchison

Bower C 'Virginity testing: In whose interest?' (November 2005) Aids Law Quarterly

Bryson V 'Modern radical feminism: Knowledge, language and patriarchy' in Bryson V Feminist political theory: An introduction (1992) London: MacMillan

Combrinck $\mathrm{H}$ and Wakefield L 'Section 2: Understanding the context' in Combrinck $\mathrm{H}$ and Wakefield $\mathrm{L}$ At the crossroads: Linking strategic frameworks to address gender-based violence and HIV/AIDS in Southern Africa Bellville: Community Law Centre, University of the Western Cape

Cook RJ 'State accountability under the Convention on the Elimination of All Forms of Discrimination Against Women' in Cook RJ (ed) Human rights of women: National and international perspectives (1994) Philadelphia: University of Pennsylvania Press

De Waal J and Currie I 'Limitation of rights' in De Waal J and Currie I The Bill of Rights handbook (2005) Lansdowne: Juta

Domestic Abuse Intervention Project, 206 West Fourth Street, Duluth, Minnesota, 55806, 218-722-4134

Fallon R 'What is republicanism and is it worth reviving?' (1989) 102 Harvard Law Review

Gardbaum S ‘Law, politics and the claims of community’ (1992) 90 Michigan Law Review

Hanmer J 'Violence and the social control of women' in Littlejohn G et al Power and the state (1978) London: Routledge

Herness $H$ 'The welfare state, citizenship and Scandinavian women' in Jones $\mathrm{K}$ and Jonasdottir A (eds) The political interests of gender: Developing theory and research with a human face (1988) London: Sage

Hlongwa W 'Teens turn to anal sex to keep virginity', cited in Bower C 'Virginity testing: In whose interest?' (November 2005) Aids Legal Quarterly

Howard $\mathrm{R}$ 'Communitarianism and liberalism in the debates on human rights in Africa' (1992) 11 Journal of Contemporary African Studies

Inter-African Committee on Traditional Practices Affecting the Health of Women and Children Report on the regional seminar on traditional practices affecting the health of women and children in Africa Inter-African Committee April 1987 and November 1990

Itzin C 'Pornography and the social construction of sexual inequality' in Itzin C (ed) Pornography, violence and civil liberties (1992) New York: Oxford University Press 
Jagwanth S and Kalula E 'Preface' in Jagwanth S and Kalula E (eds) Equality law: Reflections from South Africa and elsewhere (2001) Lansdowne: Juta

MacKinnon CA 'Feminism, Marxism, method, and the state: Toward feminist jurisprudence' (1983) 8 Signs: Journal of Women in Culture and Society

MacKinnon CA 'The liberal state' in MacKinnon CA Toward a feminist theory of the state (1989) Cambridge: Harvard University Press

Morar NS and Karim SSA 'Vaginal insertion and douching practices among sex workers at truck stops in KwaZulu-Natal' (1998) 88 South African Medical Journal

Murray R 'The notion of a state' in Murray R (ed) The Commission on Human and Peoples' Rights and international law (2000) London: Routledge

Rubin G 'Feminism and participatory democracy: Some reflections on sexual difference and citizenship' in Kemp S and Squires J (eds) Feminisms (1997) Oxford: Oxford University Press

Sanders AJGM 'On African socialism and natural law thinking' (1978) 11 Comparative and International Law Journal of Southern Africa

Sanders AJGM 'On African socialism and the rule of law' (1982) 15 Comparative and International Law Journal of Southern Africa

Siim B 'Welfare state, gender politics and equality principles: Women's citizenship in the Scandinavian welfare state' in Meehan E and Sevenhuijsen S (eds) Equality principles and politics (1991) London: Sage

Smart C Feminism and the power of law (1989) London: Routledge

Sohn L 'Protection of individuals' (1982) 32 American Law Review

South African Human Rights Commission Position paper: Virginity testing (July 2005)

Steinem G 'Erotica and pornography: A clear and present difference' in Lederer L (ed) Take back the night: Women on pornography (1982) New York: William Morrow

Umezurike O 'The status of human rights' (1995) 5 Constitutional Rights Journal

Vance CS 'Pleasure and danger: Toward a politics of sexuality' in Vance CS (ed) Pleasure and danger: Exploring female sexuality (1992) London: Pandora Press

Van der Poll L The constitutionality of pornography (2001) Unpublished LLD thesis, University of Stellenbosch

Van der Poll L 'The emerging jurisprudence on sexual violence perpetrated against women during armed conflict' (2007) African Yearbook on International Humanitarian Law

Wallace RMM and Dale-Risk K International human rights: Text and materials (2001) London: Sweet \& Maxwell 